\title{
Hermeneutics of the Holy Trinity icon by Andrei Rublev, a testimony of Church's mission in the context of secular society
}

\section{Vlad-Ioan BONDRE*}

Abstract: Holding the Truth as a definition, the icon of the Holy Trinity is nothing else but a reflection of the past, present and future, because its contents are complete principles of salvation in the love of God. Transcending the effective representation in the expression of the direct aspiration of worship, means that the Trinity gives rationality and sacred feelings to the world. Although there is a vacuum in the space of the Old Testament, the Holy Trinity icon represents nothing else, but a preparation for the New Law. The supreme gesture of love between the Holy Trinity Persons shows how the Church's mission works in the world. The Church's mission through the work of the Father, Son and Holy Spirit is the answer given to secular humanity. The iconographic representation of Saint Andrei Rublev wants to show two aspects: the deification of man by the quality of the observer and the beauty of living in a religious community that opens oneself to other people. The Mamre Oak analogy event causes observers to participate effectively in the feast of faith. For this reason, Andrei Rublev sees the roundtable as a form of reconciliation with God, through Holy Communion. The testament of the Russian painter offers believers the opportunity to live fully,

* PhD Candidate, Faculty of Orthodox Theology at the "1 Decembrie 1918" University, Alba Iulia, Romania. 
with those spiritual elements represented in the icon. The hermeneutics of Holy Trinity icon, shows therefore, the man called to the feast of love, ready to become a partaker of communion.

Keywords: icon, Rublev, mission, Trinity, secularization

\section{Introduction}

In a confusion of religious feelings, the contemporary man tries to identify with his primordial nature, the image and likeness of God. Out of subjectivity operate the term person, reporting the entire creation, which outlines an icon image with the man who is called to a perfect spiritual dynamism through direct communion with the Holy Trinity. "The Christological aspect of the relationship God-man does not reduce the absolute size of relationship with God, because man clothed in Christ means the dynamism of holiness of the Holy Spirit, which places man in communion with God the Father, Son and Holy Spirit".

The reality note is discordant, because there is an excess of individualism, a diverse culture, who marginalizing the community to live in perfect faith. The decline cohesion secularized society is a symptom of a broader ideology in understanding the supernaturalistic system defined by love. The decline is actually a request, a lack of common interest, of living in a permanent relationship with each other ${ }^{2}$. Man refuses to see the truth, reason to believe that the programs and Church's mission are a new business, thus, rejecting the view of religious institutions who work hard to call people to eternal salvation ${ }^{3}$.

${ }^{1}$ Alexandru BuZALIC, De Trinitate, Târgu Lăpuş, Galaxia Gutenberg, 2010, p. 291.

${ }^{2}$ Steve BRUCE, "Secularization, Church and Popular Religion", in Journal of Ecclesiastical History, no. 3/2011, p. 544.

${ }^{3}$ Dudley HaLl, Out of the Confort Zone - The Church in Transition, Pineville, Ph. Morning Star Publication, 1991, p. 35-37. 
Church gift offers special features, and understanding that the church is not a human construction, who gives the freedom to place the power to make all be like one (John 17:11).

\section{Missionary testimony in the icon of The Holy Trinity}

The permanent relationship between Father, Son and Holy Spirit is felt in the Divine Liturgy or in an image of common religious feelings, man being just an observer taking part in the Holy Trinity action. The Church's mission determines a man to wear qahal's image, but also the Ecclesia, thus showing that he is a communion with glory and worship.

In this context, as an allegory, the Holy Trinity icon by Andrei Rublev state the idea of unity and Church mission, because the Church is the visible face of the Trinity love $e^{4}$. Under this form of unity, Church' mission is presented as a reflection of the relationship between the Father, Son and Holy Spirit or a reflection of a deified human image. The Holy Trinity icon by Andrei Rublev, indicates that the mission is not only a human project, whose contractor is the man called to serve, but that plan is the God of Trinity. The roundtable underlying the Three Persons of the Holy Trinity as an analogy means communion and mission. As a new perspective in which man takes part as an observer at this stage, we can observe some hermeneutic aspects the Holy Trinity icon by Andrei Rublev. Church's mission is to call all nations to live the ultimate truth, this thing can be identified with some aspects of color and symbolic Byzantine iconographer.

The picture of the Holy Trinity icon by Andrei Rublev goes deep into the old version of Law Testament, including a switch to objective salvation by subjective choice of Abraham in leading the

${ }^{4}$ Christine ChaILlot, "Contemplating Rublev's Icon-The Authority of the Trinity and the Community of Women and Men in the Church", in The Ecumenicanl Review, no. 1-2/2008, p. 144. 
chosen people 5 . For this reason, Genesis 19, 1-30 shows Trinitarian revelation episode of Mamre. Those three angels will acquire a dogmatic understanding should not be overlooked some missionaries elements shows by Andrei Rublev. The first one is a rectangular table, which represents creation who is called to communion and joy. Moreover, behind on the left angel we can see a house with open doors, showing all live on this earth must fulfill our duty as sons of God, keeping a relationship based on worship glory and honor ${ }^{6}$. Dogmatic and missionary analysis of the Holy Trinity icon by Andrei Rublev, needs deep research, because many philosophers and teachers have sought to identify the version of Abraham Episode hospitality, as a Theophany of God.

Pillow plays an allegorical interpretation, arguing that the three angels are there self benefactor and sovereign power of God. Hence, he sees three people, because it couldn't give Abraham a prerequisite for revealing understanding. In contrast, Origen says that the discovery of the uncreated light which God gave to Abraham was conditioned to see. Josephus Flavius says that the three angels took human form, conduct human activities such as eating and drinking?

Other missionary symbols of the Holy Trinity icon by Andrei Rublev are identified by Anita Strezova by referring to heads position of the three angels bowed in silent conversation, as

${ }^{5}$ Vladimir PRELIPCEAN /Nicolae NEAGA /Gheorghe BARNA /Mircea CHIALDA, Studiul Vechiului Testament, București, Institutul Biblic și de Misiune al Bisericii Ortodoxe Române, 1985, p. 111.

6 Stephen AWARE, "Perspectives in Mission Today", in Columban Missionaries Britain, no. 26/ Oct. 2016, online journal at http//www.columbans.co.uk/news/perspectives-mission-today (accessed on 09.01.2017).

7 Anita Strezova, Hesychasm and Art - The Appearance of New Iconographic Trends in Byzantine and Slavic Land in the 14th adn 15 th Centuries, Canberra, ANU PRESS, 2014, p. 175. 
some theologians will assess the dialogue of the Three. The restore mission by communion is shown by the circular motion of the angel's hands, symbols which are added in the middle of the blessing angel, and providing the observer communion ${ }^{8}$. From there, you can open two perspectives: that of the Lamb, the symbol of the Eucharistic Sacrifice, with the representation made worship the Son with the Father, as a confirmation of the act of sacrifice (Matthew 26.39) and sacrifice which Abraham brings the doer of God's will, showing through the last mission authentic faith which man is called. The first perspective we find to the John Gospeller (John 1.36), who is witness to the events that has undergone the Jesus Christ, but he also sees "the Lamb in glory - Jesus scarred hands and feet, one man, around the eternal glory that bears witness sufferings of the present time" .

Arranged in a dogmatic form, the Holy Trinity icon by Andrei Rublev, expresses the idea of hierarchy. The three angels bear the mark of universality, a form of missionary through the observer is called to take part. Seated from left to right, the Trinity persons can be identified easily. Father, dressed in shades of pink, lilac, is confirmed by the presence of a house in the background, which certifies the identity of the Creator. In this regard, he confirmed that the Church's mission is a work that was based on the creation of the world. Highlighted in blue tones loud, Jesus bears mysteriously, the Church's mission, which is certified by the tree in the background, which is actually the tree of the Cross or act of reconciliation with God. The Holy Spirit, fill color range, is painted in shades of purple with silvery green transparency, behind which lies a mountain, as a symbol of spiritual height that lifts us through the grace given in the

\footnotetext{
${ }^{8}$ Ibidem, p. 190-192.

${ }^{9}$ Hamilton SMITH, "Mielul lui Dumnezeu", in Comori.org, 2014, p. 3.
} 
Sacraments ${ }^{10}$. In this painting, there is no hierarchy of subordination, Alfred Schutze is seen as an attempt by man to take part in the deification by grace, where "Father's world can be proven. The Son's world opens only to the free will of the human ego, not due to external visions, but the inner vision of Christ that the self can rise" $"$.

The testimony that the Church does in the context of the secularized world is represented by the Holy Trinity as a permanent symbol of love of the whole creation. The mission is the action of the Father, Son and Holy Spirit, and these are actions of love that call all the communion of grace and truth. Acquiring this mission by man is shown by St. Paul (I Corinthians 1:17), by bearing the Cross of Christ, that power of faith in the context of the secularized world ${ }^{12}$. Modernity wants to show that all things were linear, but the Church's mission is based on three ropes intertwined, as a symbol of the Holy Trinity ${ }^{13}$.

One aspect of secular society is that man does not fulfill the image of the Trinity only on Sundays and religious indifference shown over the week. Secularism excludes a man from the path to the transcendent, which totally changes his vision of phenomena surrounding $\mathrm{it}^{14}$. Although secularism did not embrace all aspects of contemporary society, certainly it is a different matter of iconographic art. Power sacredness inspired men such as St. Andrei Rubliov, which is why from the traditional to the

${ }^{10}$ Dmitri S. LiHACIOV, Prerenașterea rusă , București, Meridiane, 1975, p. 185.

11 Alfred Schutze, Despre Ființa Trinității, Cluj-Napoca, Triade, 2010, p. 142.

12 James A. Scherer /Stephen B. Bevans, New Directions in Mission and Evanghelization, New York, Orbis Books, 1992, p. 60-61.

13 Jon E. SingLetARY, "The Emergent Journey of Church - Based Program Plamming", in Social Word and Christianity, no. 2/2009, p. 193.

${ }^{14}$ David KIM / David McCALMAN / Dan FISHER, "The Sacred/Secular Divide and the Christian Worldview", in J. Bus Ethics, no. 109/2012, p. 205. 
innovative idea of the sacred are affected. In the traditional sacred there is an extension of the Holy Trinity. In the modern part of the constitution assumed authority,there is revelation bearing the seal of falsehood, focusing on the skeptical nature ${ }^{15}$.

\section{Spirituality in the vision of St. Andrei Rublev}

The Holy Trinity icon by Andrei Rublev representing a mirror of the heavenly world, a moment of exchange between transcendent reality, and spirit created by God. Influenced by the fifteenth century iconography, Rublev combines two existing styles before trying to play rationally feelings of love of the Three Persons third. The Christology presents, the central angel in a deeper perspective. He is painted larger than the other two, and his face was located towards the observer, so that it can accept Triune. Current tradition shows angels equal in size and the peculiarities of each of them. Gestures indicate a relationship of love, intersecting this time with the eyes of the observer. Rublev put a perichoresis into the two iconic models. The peculiarity is the observatory, which is part of the icon. In this regard, the central angel is one who approaches the table, not the observer. He wants to show that in the liturgical life, the priest is approaching the table, being away from the people. The trace of Rublev and void, wants to influence the observer to participate effectively in eternity, to step into the image, to reveal God ${ }^{16}$.

Intelligence is an attribute owned by Andrei Rubliov, which makes him one of the greatest iconograper, because he knows how to combine the graphics game between science and religion. That is why a number of his works can be found in many

${ }^{15}$ Bryan WILSON, Secularization - The Inherited Model, California, University of California Press, 1985, p. 14-15.

16 Johanes REIMER, “The Spirituality of Andrei Rublev's Icon of Holy Trinity”, in Acta Theologica Supplementum, no. 11/2008, p. 171-172. 
churches: in Moscow - 1405, Vladimir's Cathedral - 1408, Church Andronikov - 1410, Zvenigorod Church. Between 1551 the council of 100 heads of Stoglav and twentieth century, his name was linked with the Rublev painting, old style and the icon of Trinity painted between 1425-1427 were passed through an atypical work of such a great meaning. Although at first glance, it was the desire of the Russian iconographer to paint anew the communion of three persons, it seems that this icon had been painted at the request of a disciple of St. Sergius of Radonezh ${ }^{17}$. According to Pavel Florensky, it seems that it would be locked later in a silver cover and painted in dark colors, as late as 19041906 to be brought to light and painted with bright colors ${ }^{18}$.

What impresses Rublev is Abraham's hospitality episode, which was painted in the years 320-350 in the Roman catacombs or during Paleologos, because this episode of the meeting of the three angels in Mamre, become a stereotype in the Theophany of God and a way how he chose to speak directly to the chosen ones with him. Genesis presents the episode in terms of the three travelers. Abraham and Sarah welcome them with hospitality, offering them the best gifts as a token of appreciation, so we can see something special that Justin Martyr and Philosopher renders in his dialogue with his Jew Tryphon: "God appeared to Abraham before appearing three. Then the three, who word calls men, were sent angels: two of them for loss of Sodom, and one to preach Sarah, that she will have a baby. For this was sent and fulfilling its mission, it has departed "19. To understand the mystery of the Epiphany, St. Iustin Martyr and Philosopher appeal to a dogmatic

17 Paul Evdochimov, Arta icoanei - O teologie a frumuseții, București, Meridiane, 1992, p. 208.

${ }^{18}$ Robert BIRD, Andrei Rublev, Londra, British Film Institute, 2004, p. 12-17.

${ }^{19}$ St. JUSTIN THE MARTYR AND FILOSOFER, "Dialog cu Iudeul Trifon", in PSB, no. 2, București, Institutul Biblic și de Misiune al Bisericii Ortodoxe Române, 1980, p. 153. 
formula to an accessible understanding, showing that "Those three is God and is called angel" ${ }^{20}$. In the Ecumenical Councils, holy fathers teaching that "the three e persons have the same divine being, and that there is one God and not three"21. Such formulation eliminates any discussion on the presence of one person at Abraham's tent because as welcome, he calls the three "Lord" (Genesis 19.3). In this connection, St. John Chrysostom says, "Abraham says right: God, as if speaking to one man when three were the ones he's received. It may seem that I was one of those who came more honorable and therefore he addressed his request" 22 .

Transforming God, as a guest, prompted Abraham to have an attitude of love and sacrifice. This simple gesture of the hospitable likeness of Abraham, shows clearly that he was filled with love of the Three. The representation icon of supreme gesture of absolute love can be considered true knowledge of the mysteries of God, knowledge beyond human knowledge, but still accessible as ideal. For this reason, Rublev tried to compose new forms of representation, as to be as close to reality. The success is obvious, because it is the quintessence of all theological ideas about the triune God.

\section{Conclusion}

For Andrei Rubliov, appearing of thirds angels at Mamre Oak is an epiphany of the Holy Trinity Persons. His waving brushes capture its specific features and nuances of Holy Persons, showing the perfect structure of supreme love. Associating

${ }^{20}$ Ibidem, p. 154.

${ }^{21}$ Isidor TODORAN / Ioan ZăGREAN, Dogmatica Ortodoxă - Manual pentru seminariile teologice, Cluj-Napoca, Renaşterea, 2006, p. 110-111.

22 St. John Chrysostom, "Omilii la Facere (II)", in P.S.B no. 22, București, Institutul Biblic și de Misiune al Bisericii Ortodoxe Române, 1989, p. 85. 
symbols of the Father, Son and Holy Spirit, Russian iconographer transcends beyond the event of meeting the three angels with Abraham and Sarah, expressing through the painting mystery of the above in mind, and the spiritual unity of the three hypostases. The Holy Trinity icon by Andrei Rublev is a proportionality of biblical events. For this reason, Marius Oprescu says that "at the Mamre Oak wasn't showed whole Trinity, but only the Son, the second person of the Trinity, with two angels. Only the number "three" can be considered a foreshadowing of the three Persons of the Trinity and not a personal apparition"23.

If hermeneutics icon of Trinity directly certifies the relationship of love between Father, Son and Holy Spirit, the Church's mission come as a testimony to those who lived in communion. Holy Trinity is the Church's mystery, which in a secularized society, tries to wake up to the truth those swept by despair. Son's work is a dual one, as it includes obedience to the Father and the Holy Spirit blessing and responsibility of the Head of the Church. In this regard, Saint Augustine says this: "Because Christ the Lord wanted to come and live with us as a form of the edifice of His, said: I give you a new commandment, to love everyone as yourself ...; this house is high worldwide ... “24.

The Holy Trinity icon by Andrei Rublev can be considered an update of the gesture, though God opens to man or caught up in the lure of contemporary societies. In this sense, God "is the guest who guides man out of this dark tunnel. God makes that

${ }^{23}$ Marius Daniel OpRESCU, "Treime sau Logos la stejarul Mamvri? - O cercetare istorico-dogmatică", in Text și discurs religios, $3^{\text {rd }}$ ed., Iaşi, Universitatea "Alexandru Ioan Cuza", 2010, p. 297.

${ }^{24}$ Sermo 336, 1, 6, (PL 38, 1471-1475) apud. Vasile NeCHITA, "Dogma Sfintei Treimi și importanța ei pentru misiunea Bisericii”, in Analele științifice ale Universităţii “Alexandru I. Cuza”, Iaşi, no. 10/2005, p. 80. 
step which man does not know how and does not dare to do. Man takes not see God, so God sees the man, finds and visits him“25.

\section{References}

1. BIBLIA sau SFÂNTA SCRIPTURĂ, tipărită sub îndrumarea și cu purtarea de grijă a Prea Fericitului Părinte Teoctist, Patriarhul Bisericii Ortodoxe Române, cu aprobarea Sfântului Sinod, București, Institutul Biblic și de Misiune al Bisericii Ortodoxe Române, 2001.

2. BIRD, Robert, Andrei Rublev, Londra, British Film Institute, 2004.

3. BRUCE, Steve, "Secularization, Church and Popular Religion", in Jnl of Ecclesiastical History, no. 3/2011.

4. BuZALIC, Alexandru, De Trinitate, Târgu Lăpuș, Galaxia Gutenberg, 2010.

5. Chaillot, Christine, “Contemplating Rublev's Icon - The Authority of the Trinity and the Community of Women and Men in the Church", in The Ecumenicanl Review, no. 1-2/2008.

6. Evdochimov, Paul, Arta icoanei - O teologie a frumuseții, București, Meridiane, 1992.

7. HaLl, Dudley, Out of the Confort Zone - The Church in Transition, Pineville, Morning Star Publication, 1991.

8. KIM, David / MCCALMAN David / FISHER Dan, "The Sacred/Secular Divide and the Christian Worldview", in J. Bus Ethics, no. 109/2012.

9. LiHACIOV, S. Dmitri, Prerenașterea rusă, București, Meridiane, 1975.

10. NECHITA, Vasile, "Dogma Sfintei Treimi şi importanţa ei pentru misiunea Bisericii”, in Analele științifice ale Universității „Alexandru I. Cuza”, Iaşi, no. 10/2005.

11. OPRESCU, Marius Daniel, "Treime sau Logos la stejarul Mamvri? - O cercetare istorico-dogmatică”, in Text şi discurs religios, $3^{\text {rd }}$ edition, Iași, Universitatea „Alexandru Ioan Cuza”, 2010.

25 Tomas SPIDLIK /Marko Ivan RUPNIK, Credință și icoană, Cluj-Napoca, Dacia, 2002, p. 27. 
12. PRELIPCEAN, Vladimir / NEAGA Nicolae / BARNA Gheorghe/ CHIALDA Mircea, Studiul Vechiului Testament, București, Institutul Biblic și de Misiune al Bisericii Ortodoxe Române, 1985.

13. REIMER Johanes, "The Spirituality of Andrei Rublev's Icon of Holy Trinity", in Acta Theologica Supplementum, no. 11/2008.

14. Scherer, A. James / BeVANS, Stephen B., New Directions in Mission and Evanghelization, New York, Ph. Orbis Books, 1992.

15. SchuTZE, Alfred, Despre Ființa Trinității, Cluj-Napoca, Triade, 2010.

16.St. John Chrysostome, "Omilii la Facere (II)”, in P.S.B, no. 22, București, Institutul Biblic și de Misiune al Bisericii Ortodoxe Române, 1989.

17. St. IUSTiN THE MARTYR AND FILOSOFER, "Dialog cu Iudeul Trifon”, in P.S.B, no. 2, București, Institutul Biblic și de Misiune al Bisericii Ortodoxe Române, 1980.

18. SingletARY, E. Jon, "The Emergent Journey of Church Based Program Plamming", in Social Word and Christianity, no. 2/2009.

19. SMITH, Hamilton, "Mielul lui Dumnezeu", in Comori.org, 2014.

20. SPIDLIK, Tomas / RUPNIK, Marko Ivan, Credință şi icoană, Cluj-Napoca, Dacia, 2002.

21. StrezOVA, Anita, Hesychasm and Art - The Appearance of New Iconographic Trends in Byzantine and Slavic Land in the 14th adn 15 th Centuries, Canberra, ANU PRESS, 2014.

22. TODORAN, Isidor / ZăGREAN Ioan, Dogmatica Ortodoxă - Manual pentru seminariile teologice, Cluj-Napoca, Renașterea, 2006.

23. WILson, Bryan, Secularization - The Inherited Model, California, University of California Press, 1985.

\section{Web sources:}

24. Stephen AWARE, "Perspectives in Mission Today", in Columban Missionaries Britain, no. 26/ Oct. 2016, online journal at http//www.columbans.co.uk/news/perspectivesmission-today (accessed on 09.01.2017). 